Gromyko, O., Tistechok, S., Roman, I., Aravitska, O., Luzhetskyy, A.,

Parnikoza, I., Fedorenko, V. (2021). Isolation and characterization

of culturable actinobacteria associated with Polytrichum strictum

(Galindez Island, the maritime Antarctic).

Ukrainian Antarctic Journal, 1, 82-97.

https://doi.org/10.33275/1727-7485.1.2021.668

\author{
O. Gromyko, *, S. Tistechok ${ }^{1}$, I. Roman ${ }^{1}$, O. Aravitska ${ }^{1}$, \\ A. Luzhetskyy ${ }^{4}$, I. Parnikoza ${ }^{2,3}$, V. Fedorenko ${ }^{1}$ \\ ${ }^{1}$ Ivan Franko National University of Lviv, Lviv, 79005, Ukraine \\ ${ }^{2}$ State Institution National Antarctic Scientific Center, \\ Ministry of Education and Science of Ukraine, Kyiv, 01601, Ukraine \\ ${ }^{3}$ Institute of Molecular Biology and Genetic NAS of Ukraine, Kyiv, 03143, Ukraine \\ ${ }^{4}$ Saarland University, Saarbrücken, 66123, Germany \\ * Corresponding author: oleksandr.gromyko@lnu.edu.ua
}

\title{
Isolation and characterization of culturable actinobacteria associated with Polytrichum strictum (Galindez Island, the maritime Antarctic)
}

\begin{abstract}
The main objective of the study is the evaluation of the diversity of actinobacteria associated with Polytrichum strictum dominant species of widespread Antarctic Tall moss turf subformation and their characteristics as the producers of biologically active compounds. The actinobacterial isolates were isolated by direct inoculation, phenol pretreatment, and heated treatment. The cultural properties of the isolates were evaluated using diagnostic media. The antimicrobial activity of the isolates was determined by the point inoculations method. The phylogenetic analysis was based on sequence analysis of the 16S rRNA gene. The biosynthetic genes screening was performed using polymerase chain reaction. A total of 23 actinobacterial isolates associated with $P$. strictum were isolated, the four identified genera being Streptomyces ( 7 isolates), Micromonospora (14 isolates), Kribbella (1 isolate), and Micrococcus (1 isolate). Eight psychrotrophic strains of all identified genera were identified. The optimal $\mathrm{pH}$ values for all isolates were in the range 6-10. Four isolates grew on the medium with $7.5 \% \mathrm{NaCl}$. A significant number of the isolates showed a wide range of enzymatic activities. Antagonists of a wide range of pathogenic microorganisms were found, including against multidrug-resistant strain of Candida albicans and Methicillin-resistant Staphylococcus aureus. Some strains were active against phytopathogenic bacteria, namely three strains against Erwinia amylovora, one strain against Agrobacterium tumefaciens, and one strain against Pectobacterium carotovorum. More than half of the isolates showed antifungal activity against Fusarium oxysporum and Aspergillus niger. The biosynthetic genes involved in synthesizing a wide range of bioactive compounds were found in more than $80 \%$ of isolates. Antarctic actinobacteria isolated in this study demonstrate potential as the producers of a wide range of biologically active compounds. Further studies of these actinobacteria may lead to the identification of previously unknown biologically active compounds.
\end{abstract}

Keywords: Antarctic actinobacteria, Polytrichum strictum, antimicrobial activity, biosynthetic genes

\section{Introduction}

Galindez Island belongs to the Argentine Islands (the maritime Antarctic), which are composed of different rocks favorable for the development of vegetation. Meanwhile, the vegetation of these islands is considerably limited in diversity. In summer, it occupies most of the ice-free areas. It includes Tall moss turf subformation, Bryophyte mat and carpet subformation, Fruticose lichen and moss cushion subformation, etc. The first community type forms the most extensive continuous stands, the moss banks. They are dominated by the moss Polytrichum strictum Menzies ex. Brid. 1801 (Polytrichaceae) (Parnikoza et al., 2018). The Antarctic microbiota, on the other hand, is quite diverse (Molina-Montenegro et al., 2019). 
Among the bacteria, one of the most common is the phylum Actinobacteria, in particular, the order Actinomycetales (Pudasaini et al., 2017). The phylum Actinobacteria includes gram-positive bacteria with high $\mathrm{G}+\mathrm{C}$ content. The individual genera (Streptomyces, Streptoverticillium, etc.) form branched mycelium (Petrus \& Claessen, 2014). These microorganisms play an important environmental role as soil-forming bacteria, and also they are a part of the plants' rhizosphere (Sathya et al., 2017). The rhizosphere microorganisms of the Antarctic, including actinobacteria, can produce cold-shock proteins, cold-active enzymes, antifreeze enzymes, and polysaccharides, providing tolerance to temperature changes but also indirectly protecting plants from the extremely cold climate (Raymond, 2016; Muñoz et al., 2017).

Actinobacteria are well known as producers of a wide range of bioactive compounds (Ding et al., 2019). These bacteria, especially the genus Streptomyces, are major targets of microbial biotechnology as producers of most currently known antibiotics (Liu et al., 2018). Antimicrobial, antitumour, antiparasitic, and other drugs based on natural actinomycete products are widely used in medicine, including veterinary (Baltz, 2019). Therefore, the isolation and study of actinobacteria from natural habitats are relevant.

The study of the diversity of actinobacteria from poorly explored biotopes is a promising strategy for identifying new biologically active compounds or their producers (Núñez-Montero \& Barrientos, 2018). This is especially relevant today because the ever-increasing number of multidrug-resistant (MDR) pathogenic microorganisms requires regular screening of new antibiotics. The analysis of the biotechnological potential of actinomycetes from the Crimean Peninsula (Ukraine), still poorly explored, allowed identifying more than ten new biologically active compounds (Raju et al., 2013; Raju et al., 2015). One of them is leopolic acid (Raju et al., 2012), which is considered today a potential antiviral drug against SARS-CoV-2 (Mazzini et al., 2020). This renders the perspective of screening studies in poorly studied biotopes, as the Antarctic.

This study is a continuation of our previous studies on the diversity of Antarctic actinobacteria. It focuses on the isolation and characterization of actinobacteria associated with $P$. strictum, the dominant moss of the Tall moss turf subformation from Galindez Island.

\section{Materials and methods}

\subsection{Isolation of actinobacteria}

The rhizoid samples of the P. strictum from moss bank were collected on the Galindez Island, the Argentine Islands, the maritime Antarctic ( $-65.24615^{\circ}$, $\left.-64.24969^{\circ}\right)$ during the 21st Ukrainian Antarctic Expedition in 2017. The plants of the P. strictum were without signs of disease, and the $\mathrm{pH}$ of the soil -5.1 . The samples were transported into sterile containers to the laboratory of the Microbial Culture Collection of Antibiotic Producers of the Ivan Franko National University of Lviv (MCCAP LNU). The actinobacteria were isolated using three different methods: I rhizoid samples (2 grams) were placed in flasks with $100 \mathrm{ml}$ of sterile tap water and shaken for $15 \mathrm{~min}$; II rhizoid samples (2 grams) were placed in flasks with $1.5 \%$ aqueous phenol solution and shaken for $30 \mathrm{~min}$; III - rhizoid samples ( 2 grams) were heated for 60 min at $100{ }^{\circ} \mathrm{C}$ and then treated the same as method I. Methods II and III were applied to inhibit fast-growing microorganisms, including streptomycetes, to isolate slow-growing actinomycetes, such as Micromonospora spp. Further, the ten-fold serial dilutions of the samples were plated $\left(10^{-1}-10^{-5}\right)$ on the OM (Gromyko, 2012), ISP4 (Kieser et al., 2000), SA (HiMedia), and HVA (Zhang \& Zhang, 2011) media. Nalidixic acid $(25 \mu \mathrm{g} / \mathrm{ml})$ and nystatin $(50 \mu \mathrm{g} / \mathrm{ml})$ were added to isolation media to inhibit the growth of other bacteria and fungi. The plates were incubated at $28^{\circ} \mathrm{C}$ for 30 days. The colonies with actinobacteria-like morphology were selected. The pure cultures of the isolates were stored in TSB medium (Kieser et al., $2000)$ at $-80^{\circ} \mathrm{C}$ in $25 \%$ (v/v) glycerol. These isolates were deposited in the MCCAP LNU.

\subsection{S rRNA gene sequencing and analysis}

The isolates were cultured in Tryptic Soy Broth (TSB) (HiMedia Laboratories Pvt Ltd., India) at a temperature of $28^{\circ} \mathrm{C}$ for $3-5$ days and a shaking rate of $180 \mathrm{rpm}$. 
The total DNA was isolated as described by Kieser et al. (2000). The amplification of the $16 \mathrm{~S}$ rRNA gene was done using primers (Table 1). The polymerase chain reaction (PCR) was carried out in a total volume of $50 \mu$ containing $2.0 \mu \mathrm{l}$ of genomic DNA $(\sim 50 \mathrm{ng})$, $1.0 \mu \mathrm{l}$ of each primer (10 pmol), $2.5 \mu \mathrm{l}$ of dimethyl sulfoxide, $2.0 \mu \mathrm{l}$ of deoxynucleotide triphosphates (10.0 mM each), $5.0 \mu \mathrm{l}$ of $10 \times$ PCR buffer, $0.5 \mu \mathrm{l}$ of DNA polymerase $(5 \mathrm{U} / \mu \mathrm{l})$ and $36.0 \mu \mathrm{l}$ MilliQ grade water. The parameters of the PCR were as follows: the initial denaturation at $95^{\circ} \mathrm{C}$ for $5 \mathrm{~min}$, followed by 30 cycles of denaturation at $95^{\circ} \mathrm{C}$ for $30 \mathrm{~s}$, annealing at $53{ }^{\circ} \mathrm{C}$ for $30 \mathrm{~s}$ and extension at $72^{\circ} \mathrm{C}$ for $90 \mathrm{~s}$. A final extension was at $72{ }^{\circ} \mathrm{C}$ for $10 \mathrm{~min}$. The amplified PCR products of the 16S rRNA were separated by electrophoresis in 1\% agarose gel, purified using the QIAquick Gel Extraction Kit (Qiagen, Venlo, Netherlands), and sequenced with the amplification primers by Eurofins Genomics (GATC Services). The forward and reverse sequences were assembled with Geneious software version 9.1.3 (Kearse et al., 2012).

The analysis of the 16S rRNA gene sequence of the actinobacteria isolates was performed by RDP
Release 11 (Wang et al., 2007). The closest related species to the 16S rRNA were identified by BLAST search data in the National Center for Biotechnology Information database (https://blast.ncbi.nlm.nih.gov/ Blast.cgi). The phylogenetic tree was constructed using two-making algorithms neighbor-joining (NJ) (Saitou \& Nei, 1987) in MEGAX (Kumar et al., 2018). The evolutionary distances were computed according to the Kimura two-parameter method (Kimura, 1980), and the robustness of the tree topology was evaluated by the bootstrap test (1000 replicates) (Felsenstein, 1985).

\subsection{Determination of cultural properties of the actinobacterial isolates}

Growth at different temperatures. The isolates were spot-inoculated on Bennett's medium (Kieser et al., 2000) and cultivated at a temperature of 4 or $10{ }^{\circ} \mathrm{C}$ for 30 days, and 28,37 , or $45^{\circ} \mathrm{C}$ for 10 days (Strickler et al., 2015). The growth at different temperatures was identified visually.

Growth at various $\mathrm{pH}$ values. The isolates were spotinoculated on Bennett's medium with different $\mathrm{pH}$

Table 1.The PCR primers used in this work

\begin{tabular}{|c|c|c|c|}
\hline Gene & Primers & Sequence (5'-3') & References \\
\hline $16 \mathrm{~S}$ rRNA & $\begin{array}{l}8 \mathrm{~F} \\
1510 \mathrm{~F}\end{array}$ & $\begin{array}{l}\text { AGAGTTTGATYMTGGCTCAG } \\
\text { TACGGYTACCTTGTTACGACTT }\end{array}$ & Pei et al., 2010 \\
\hline PKS I & $\begin{array}{l}\text { K1 F } \\
\text { M6 R }\end{array}$ & $\begin{array}{l}\text { TSAAGTCSAACATCGGBCA } \\
\text { CGCAGGTTSCSGTACCAGTA }\end{array}$ & $\begin{array}{l}\text { Ayuso-Sacido \& } \\
\text { Genilloud, } 2005\end{array}$ \\
\hline PKS II & $\begin{array}{l}\mathrm{KS} \alpha \\
\mathrm{KS} \beta\end{array}$ & $\begin{array}{l}\text { TSGRCTACRTCAACGGSCACGG } \\
\text { TACSAGTCSWTCGCCTGGTTC }\end{array}$ & Ayuso et al., 2005 \\
\hline NRPS & $\begin{array}{l}\text { A3F } \\
\text { A7R }\end{array}$ & $\begin{array}{l}\text { GCSTACSYSATSTACACSTCSGG } \\
\text { SASGTCVCCSGTSGCGTAS }\end{array}$ & $\begin{array}{l}\text { Ayuso-Sacido \& } \\
\text { Genilloud, } 2005\end{array}$ \\
\hline CYP450 & $\begin{array}{l}\text { cypF } \\
\text { cypR }\end{array}$ & $\begin{array}{l}\text { TGGATCGGCGACGACCGSVYCGT } \\
\text { CCGWASAGSAYSCCGTCOTACTT }\end{array}$ & Han et al., 2010 \\
\hline oxyB & $\begin{array}{l}\text { oxyB F } \\
\text { oxyB R }\end{array}$ & $\begin{array}{l}\text { CTGGTCGGCAACCTGATGGAC } \\
\text { CAGGTACCGGATCAGCTCGTC }\end{array}$ & Wood et al., 2007 \\
\hline $\mathrm{HMG}-\mathrm{CoA}$ & $\begin{array}{l}\text { HMG F } \\
\text { HMG R }\end{array}$ & $\begin{array}{l}\text { GGGCATCGCCGCGACCCTCGTCGACGAGCG } \\
\text { GCGATGACGGCGAGGCGGCGGGCGTTCTC }\end{array}$ & Sigmund et al., 2003 \\
\hline $\mathrm{APH}$ & $\begin{array}{l}\text { STR-F } \\
\text { STR-R }\end{array}$ & $\begin{array}{l}\text { CGGCTGCTCGACCA CGAC } \\
\text { GTCCTCGATGTCCCACAG }\end{array}$ & Anderson et al., 2002 \\
\hline
\end{tabular}


values $(4,5,6,7,8,10,12)$ (Strickler et al., 2015). 37\% $\mathrm{HCl}$ and $10 \mathrm{NNaOH}$ were used to adjust the $\mathrm{pH}$ of the media. After seven days of incubation at $28{ }^{\circ} \mathrm{C}$, the growth at various $\mathrm{pH}$ values was identified visually.

Growth at different $\mathrm{NaCl}$ concentrations. The isolates were spot-inoculated on Bennett's medium with different $\mathrm{NaCl}$ concentration $(2.5 \%, 5 \%, 7.5 \%$ and $10 \%$ ) (Moradi et al., 2011). After seven days of incubation at $28{ }^{\circ} \mathrm{C}$, the growth at different $\mathrm{NaCl}$ concentrations was identified visually.

Pectinase activity. The pectinase activity was determined in a medium containing $0.5 \%$ of pectin (Sigma-Aldrich). The isolates were spot-inoculated, and after seven days of incubation at $28^{\circ} \mathrm{C}$, the pectinase activity was identified by the appearance of a clear zone around the colony after pouring plates with a $1 \%$ Hexadecytrimethyl-ammonium bromide solution for 30 min (Elbeltagy et al., 2000).

Amylase activity. The amylase activity was determined in a medium with starch $(\mathrm{g} / \mathrm{L}$ : peptone -10 , $\mathrm{KH}_{2} \mathrm{PO}_{4}-5$, soluble starch -2 , agar $\left.-15 ; \mathrm{pH} 7.4\right)$. The isolates were spot-inoculated and after seven days of incubation at $28^{\circ} \mathrm{C}$. After culturing, the agar plates were filled with Lugol's solution and evaluated after 10 minutes. The medium containing starch was colored blue, and the hydrolysis zone remained discolored or colored reddish-brown if the starch was hydrolyzed to dextrins (Egorov, 1995).

Protease activity. The protease activity was determined in Bennett's medium containing $1 \%$ milk powder (Fluka). The isolates were spot-inoculated, and after seven days of incubation at $28^{\circ} \mathrm{C}$, the protease activity was identified by the appearance of a clear zone around the colony (Egorov, 1995).

Lecithinase activity. The lecithinase activity was determined in a medium containing $10 \%$ of the egg yolk emulsion (HiMedia) (g/L: peptone - 10, yeast extract $-5, \mathrm{NaCl}-10$, glucose -5 , agar -15 , distilled water - $900 \mathrm{ml}$; pH 7.4; after autoclaving, $100 \mathrm{ml}$ of egg yolk emulsion was added). The isolates were spotinoculated, and after seven days of incubation at $28^{\circ} \mathrm{C}$, lecithinase activity was identified by the appearance of a white zone around the colony (Bates \& Liu, 1963).

Nitrate reduction. The nitrate reduction was determined in a nitrate medium $(\mathrm{g} / \mathrm{L}$ : peptone -5 , beef extract $-3, \mathrm{KNO}_{3}-1$, agar $\left.-15 ; \mathrm{pH} 7.2\right)$. The isolates were spot-inoculated, and after seven days of incubation at $28^{\circ} \mathrm{C}$, the nitrate reduction was identified by the appearance of a pink zone around the colony after pouring plates with a Griess solution (10 g Griess reagent in $100 \mathrm{ml} \mathrm{12 \%} \mathrm{acetic} \mathrm{acid)} \mathrm{for}$ 30 min (Egorov, 1995).

Cellulase activity. The cellulase activity was determined in Bennett's medium containing $1 \%$ of the carboxymethyl cellulose (Sigma-Aldrich). The isolates were spot-inoculated, and after seven days of incubation at $28{ }^{\circ} \mathrm{C}$, the cellulase activity was identified by the appearance of a clear zone around the colony after pouring plates with a Gram's iodine solution (Iodine $-0.33 \mathrm{~g}$, Potassium iodide $-0.66 \%$, distilled water $-100 \mathrm{ml}$ ) for $20 \mathrm{~min}$ (Kasana et al., 2008).

Lipase activity. The lipase activity was determined by growing the isolates on a medium containing a lipid (Tween 20, Sigma-Aldrich) as the primary carbon source. The medium was as follows: peptone $-1.0 \mathrm{~g}$, yeast extract $-0.1 \mathrm{~g}, \mathrm{CaCl}_{2} \times \mathrm{H}_{2} \mathrm{O}-0.1 \mathrm{~g}$, agar $-18 \mathrm{~g}$, Tween $20-10 \mathrm{ml}$ (autoclaved separately from the rest of the medium), distilled water $-990 \mathrm{ml}$. The presence of the fatty acid crystals around the colony was identified as positive result (Egorov, 1995).

Laccase activity. The laccase activity was determined in Bennett's medium containing $0.01 \%$ guaiacol (Sigma-Aldrich). The isolates were spot-inoculated, and after seven days of incubation at $28^{\circ} \mathrm{C}$, the laccase activity was identified by the appearance of a brown zone around the colony (Unuofin et al., 2019).

Oxidoreductase activity (decolorisation of Azur B). The oxidoreductase activity was determined in a medium containing Azur B (Sigma-Aldrich) (g/L: peptone -5 , glucose -20 , Azur B - 0.1, agar $-15 ; \mathrm{pH}$ 7.4). The isolates were spot-inoculated, and after seven days of incubation at $28^{\circ} \mathrm{C}$, the oxidoreductase activity was identified by the appearance of a zone of the decolorization of Azur B around the colony (Levin et al., 2019).

\subsection{Screening for antimicrobial activity}

The antimicrobial activity screening was performed against Bacillus subtilis ATCC 31324, Staphylococcus 
aureus ATCC 25923, S. aureus 120 (Methicillin-resistant $S$. aureus (MRSA)), Escherichia coli ATCC 25922, Pseudomonas aeruginosa ATCC 9027, Proteus vulgaris ATCC 29905, Mycobacterium smegmatis DSM43268, Candida albicans ATCC 885-653, C. albicans 12 (MDR clinical strain), phytopathogenic bacteria $P$. syringae IMB 8511, Pectobacterium carotovorum IMB 8982, Agrobacterium tumefaciens IMB 8628, Erwinia amylovora Mi2, and fungi Fusarium oxysporum IMB 54201 and Aspergillus niger IMB 16706. The strains were obtained from the MCCAP LNU. The actinobacterial isolates were inoculated onto ISP2, DNPM, and NL19 media (Kieser et al., 2000; Axenov-Gribanov et al., 2016) at seven isolates per plate around the perimeter and cultured at $28^{\circ} \mathrm{C}$ for 14 days. The test cultures were prepared as follows: overnight cultures of the test microorganisms were adjusted to a concentration of $10^{6} \mathrm{cells} / \mathrm{ml}$, and $100 \mu \mathrm{l}$ of the test culture were added to $5 \mathrm{ml}$ of soft agar and poured onto OM plates with actinobacterial isolates. LB soft agar (g/L: 10 tryptone, $10 \mathrm{NaCl}, 5$ yeast extract, 7 agar) and Sabouraud soft agar (g/L: 10 peptone, 40 dextrose, 7 agar) were used for bacteria and yeast, respectively. The plates were incubated at $28{ }^{\circ} \mathrm{C}$ for yeast and $37^{\circ} \mathrm{C}$ for bacteria overnight. The antifungal activity against filamentous fungi was studied as follows. The isolates were inoculated on the above media in eight isolates per plate at a distance of 3-4 cm from the center. After actinobacteria incubation for 3 days at $28^{\circ} \mathrm{C}$, an agar block with a 3-day test culture of the fungus was placed in the center of the plate. The incubation resumed for 5-6 days under the same conditions. The antimicrobial activity was observed with the appearance of zones of the growth inhibition of the test cultures. All the experiments were performed in triplicate.

\subsection{Screening of biosynthetic genes}

The total DNA of isolates was screened for the presence of biosynthetic genes responsible for the synthesis of type I polyketide synthases (PKS I), type II polyketide synthases (PKS II), nonribosomal peptide synthetases (NRPS), polyene-specific P450 hydroxylase (CYP450), aminoglycoside phosphotransferase (APH), 3-hydroxy-3-methylglutaryl coenzyme A reductase (HMG-CoA), and glycopeptide monooxy- genase B gene (oxyB). The PCR amplification of these genes was performed using the primers listed in Table 1. The PCR reaction was performed in a total volume of $50 \mu \mathrm{l}$, as mentioned above. The amplification of the biosynthetic genes was carried out using the following reaction conditions:

PKS I: the template denaturation at $95^{\circ} \mathrm{C}(5 \mathrm{~min})$, followed by 40 cycles of denaturing at $95^{\circ} \mathrm{C}$ for $30 \mathrm{~s}$, annealing at $55^{\circ} \mathrm{C}$ for $60 \mathrm{~s}$, and extension at $72^{\circ} \mathrm{C}$ for $2 \mathrm{~min}$. Final extension step at $72^{\circ} \mathrm{C}$ for $10 \mathrm{~min}$.

PKS II: the template denaturation at $95^{\circ} \mathrm{C}(5 \mathrm{~min})$, followed by 35 cycles of denaturing at $95^{\circ} \mathrm{C}$ for $30 \mathrm{~s}$, annealing at $58^{\circ} \mathrm{C}$ for $60 \mathrm{~s}$, and extension at $72^{\circ} \mathrm{C}$ for $2 \mathrm{~min}$. Final extension step at $72^{\circ} \mathrm{C}$ for $10 \mathrm{~min}$.

NRPS: the template denaturation at $95^{\circ} \mathrm{C}(5 \mathrm{~min})$, followed by 35 cycles of denaturing at $95^{\circ} \mathrm{C}$ for $30 \mathrm{~s}$, annealing at $59^{\circ} \mathrm{C}$ for $60 \mathrm{~s}$, and extension at $72^{\circ} \mathrm{C}$ for $2 \mathrm{~min}$. Final extension step at $72^{\circ} \mathrm{C}$ for $5 \mathrm{~min}$.

CYP450: the template denaturation at $95^{\circ} \mathrm{C}(5 \mathrm{~min})$, followed by 30 cycles of denaturing at $95^{\circ} \mathrm{C}$ for $40 \mathrm{~s}$, annealing at $65^{\circ} \mathrm{C}$ for $60 \mathrm{~s}$, and extension at $72^{\circ} \mathrm{C}$ for $30 \mathrm{~s}$. Final extension step at $72{ }^{\circ} \mathrm{C}$ for $10 \mathrm{~min}$.

APH: the template denaturation at $95^{\circ} \mathrm{C}(5 \mathrm{~min})$, followed by 35 cycles of denaturing at $95^{\circ} \mathrm{C}$ for $30 \mathrm{~s}$, annealing at $55^{\circ} \mathrm{C}$ for $60 \mathrm{~s}$, and extension at $72^{\circ} \mathrm{C}$ for $2 \mathrm{~min}$. Final extension step at $72^{\circ} \mathrm{C}$ for $10 \mathrm{~min}$.

HMG-CoA: the template denaturation at $95^{\circ} \mathrm{C}$ ( $5 \mathrm{~min}$ ), followed by 35 cycles of denaturing at $95^{\circ} \mathrm{C}$ for $30 \mathrm{~s}$, annealing at $62^{\circ} \mathrm{C}$ for $60 \mathrm{~s}$, and extension at $72^{\circ} \mathrm{C}$ for $2 \mathrm{~min}$. Final extension step at $72^{\circ} \mathrm{C}$ for $7 \mathrm{~min}$.

OxyB: the template denaturation at $95^{\circ} \mathrm{C}(5 \mathrm{~min})$, followed by 35 cycles of denaturing at $95^{\circ} \mathrm{C}$ for $60 \mathrm{~s}$, annealing at $60^{\circ} \mathrm{C}$ for $60 \mathrm{~s}$, and extension at $72^{\circ} \mathrm{C}$ for $2 \mathrm{~min}$. Final extension step at $72^{\circ} \mathrm{C}$ for $5 \mathrm{~min}$.

The presence of biosynthetic genes was determined based on the appearance of amplicons of appropriate sizes following the visualization of the PCR products in agarose gel. The PCR products were visualized as described above.

\section{Results}

\subsection{Isolation and phylogenetic characterization of actinobacteria}

In this study, 23 actinobacteria-like isolates selected by morphological characteristics (the shape and color 
of colonies, the formation of substrate and aerial mycelium, and the formation of soluble pigments) were isolated (Fig. 1). The largest number of actinobacteria-like colonies was isolated after treatment of the sample with $1.5 \%$ phenol solution -17 (74\%). Only three isolates of the actinobacteria were isolated after direct inoculation, and another three from the sample were kept at $100{ }^{\circ} \mathrm{C}$ for one hour (Table 2).

The 16S rRNA gene sequence-based phylogenetic analysis showed that all the isolated bacteria belong to the class Actinobacteria. Four genera: Streptomyces (7 isolates), Micromonospora (14 isolates), Kribbella (1 isolate), and Micrococcus (1 isolate) were identified. The analysis of the phylogenetic trees demonstrates that isolates form tight monophyletic groups with representatives of the respective genera (Fig. 2).

\subsection{Determination of cultural properties of the actinobacterial isolates}

The growth of isolates was estimated in a wide range of temperatures. All the actinobacterial isolates grew well in the temperature range of $28-37^{\circ} \mathrm{C}$. Among the studied isolates, eight psychrotrophic grew well in the range of $4-37{ }^{\circ} \mathrm{C}$, and seven grew at $45^{\circ} \mathrm{C}$. The actinobacterial isolates grew well on media with $\mathrm{pH}$ from 6 to 10. Two isolates, namely Streptomyces sp. Psp 67-13 and Psp 67-15, grew in a wide range of $\mathrm{pH}$ values (4-12) and temperatures $\left(4-45{ }^{\circ} \mathrm{C}\right)$. Most isolates were sensitive to increased concentrations of $\mathrm{NaCl}$. Half of them did not grow in the presence of $2.5 \% \mathrm{NaCl}$. Only four isolates grew at $7.5 \% \mathrm{NaCl}$.

The actinobacterial isolates produced a wide range of hydrolytic enzymes (Table 3). All isolates hydrolyzed carboxymethylcellulose, and most of them, except four isolates of the genus Micromonospora, produced amylase. More than half of the isolates hydrolyzed casein, and almost half of the isolates reduced nitrate. Only five streptomycetes showed lecithinase activity. All isolates of the genus Streptomyces, half isolates of the genus Misromonospora, and Kribbella sp. Psp 67-2 produced lipase. Five of the 23 isolates produced pectinase. The Streptomyces sp. Psp 67-03 showed all these enzymatic activities. The actinobacterial isolates positive for laccase and oxidoreductase activity screenings were not detected.

\subsection{Antimicrobial activity}

All the actinobacterial isolates were screened for their ability to produce antimicrobial compounds against gram-positive, gram-negative bacteria and fungi, including MDR clinical strains, and also against phytopathogenic microorganisms. The isolates were cultured on three different media (NL19, DNPM, and ISP2) to detect antibiotic activity. Almost $80 \%$ of actinobacterial isolates demonstrated antagonistic ac-
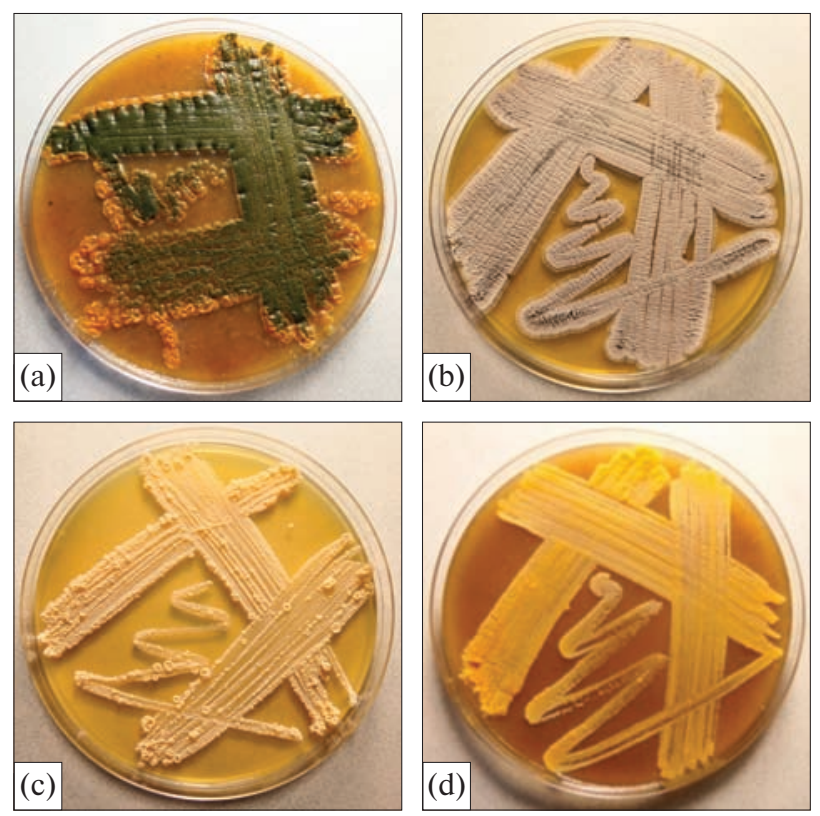

Figure 1. Selected actinobacteria isolates associated with Polytrichum strictum: (a) - Micromonospora sp. Psp 67-23, (b) Streptomyces sp. Psp 67-03, (c) - Kribbella sp. Psp 67-02, (d) Micrococcus sp. Psp 67-29

Table 2. The number of actinobacteria-like isolates associated with Polytrichum strictum

\begin{tabular}{|l|c|c|c|}
\hline \multirow{2}{*}{ Medium } & \multicolumn{3}{|c|}{ Pretreatment } \\
\cline { 2 - 4 } & $\begin{array}{c}\text { Direct } \\
\text { inoculation }\end{array}$ & Phenol 1.5\% & $\begin{array}{c}100{ }^{\circ} \mathrm{C}, \\
1 \mathrm{~h}\end{array}$ \\
\hline OM & 3 & 8 & 1 \\
ISP4 & 0 & 3 & 1 \\
HVA & 0 & 4 & 1 \\
SA & 0 & 2 & 0 \\
Total & $\mathbf{3}$ & $\mathbf{1 7}$ & $\mathbf{3}$ \\
\hline
\end{tabular}




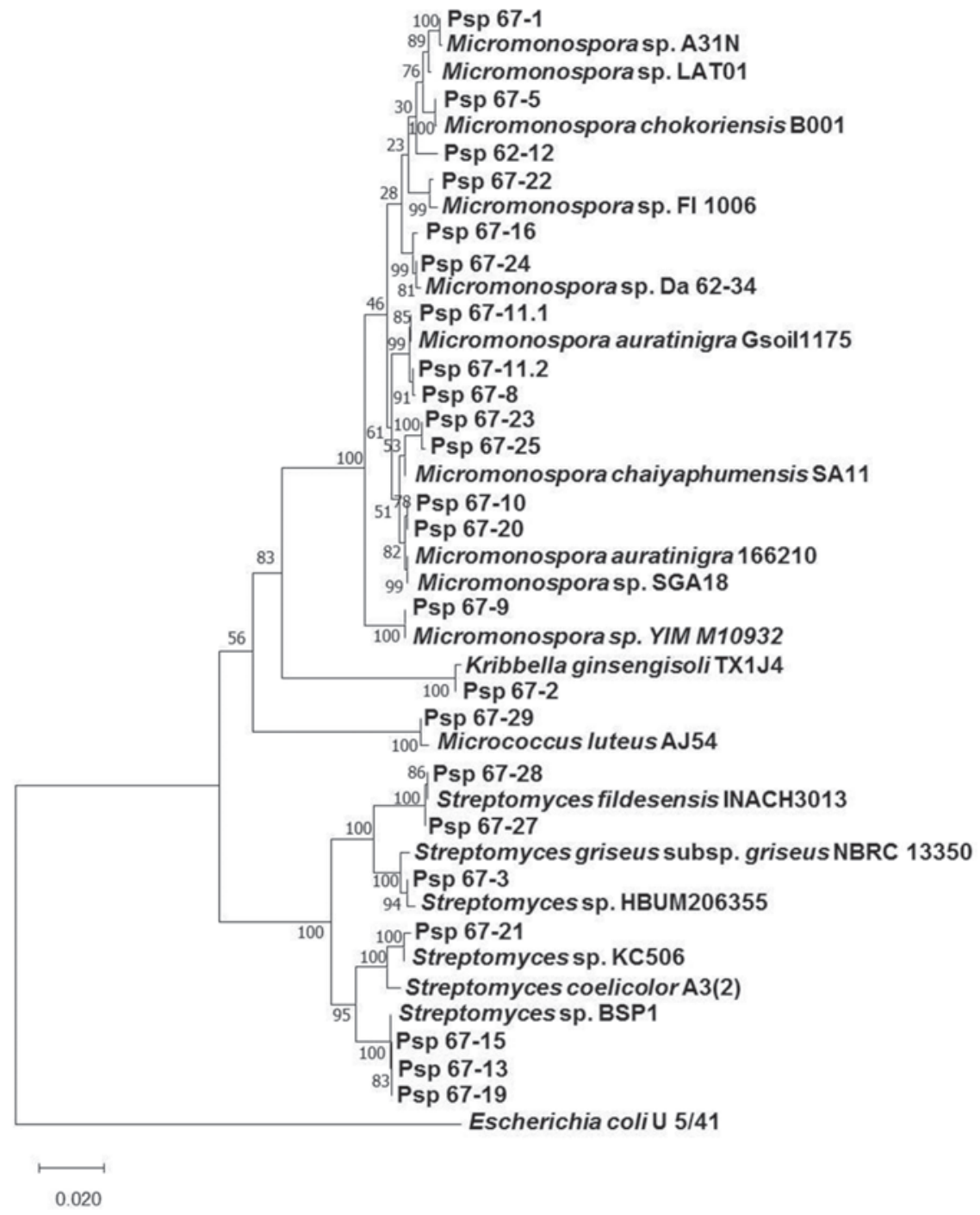

Figure 2. The 16S rRNA phylogenetic tree, showing the evolutionary relationship (the neighbor-joining algorithm) between the actinobacteria isolates associated with Polytrichum strictum, their closest homologs, and several typical members of the respective genera. The 16S rRNA gene sequence of Escherichia coli strain U5/41 was used as a root to construct a phylogenetic tree

tivity against at least one of the test cultures (Table 4). Six isolates inhibited the growth of gram-positive bacteria $B$. subtilis, S. aureus, and M. smegmatis. Only one isolate Psp 67-03, in addition to inhibiting a typical strain of the staphylococci, also inhibited the growth of MRSA. No antagonists against gram-negative clinical bacteria were detected. Three isolates of streptomycetes (Psp 67-13, Psp 67-15, Psp 67-19) demonstrated antimicrobial activity against typical and MDR strains of the C. albicans.

Some antagonists of phytopathogenic bacteria were also found. Among them, the isolates Psp 67-03 and Psp 67-27 inhibited the growth of $A$. tumefaciens and $P$. carotovorum, respectively. In turn, the three isolates ( $M i$ crococcus sp. Psp 67-29, Streptomyces sp. Psp 67-19, and Micromonospora sp. Psp 67-11.1) were antagonists of 
the E. amylovora. More than half of the actinobacterial isolates demonstrated antifungal activity against phytopathogenic filamentous fungi, and most of them inhibited the growth of both $F$. oxysporum and A. niger. The isolate Psp 67-19 showed the highest spectrum of antimicrobial activity against the used pathogens.

\subsection{Screening of biosynthetic genes}

Twenty-three actinobacterial isolates were tested using degenerate PCR primers for the presence of PKS I, PKS II, NRPS, CYP450, APH, HMG-CoA, and oxyB genes (Table 4). PKS I biosynthetic genes were detected in more than $80 \%$ of the tested isolates. Almost $70 \%$ of the isolates were positive for PKS II and CYP 450 genes screening, while APH genes were de- tected in $56 \%$ of the isolates, and isoprenoid genes in about $40 \%$ of the isolates. NRPS biosynthetic genes were identified in four isolates of the genera Streptomyces and Micromonospora, and only one isolate Psp 67-02 was positive for oxyB gene screening. Most of the Streptomyces sp. isolates as well as Kribbella $s p$. Psp 67-02 and Micrococcus sp. Psp 67-29, demonstrated a wider range of the screened biosynthetic genes than members of the genus Micromonospora.

Thus, the isolated actinobacteria contain a wide range of biosynthetic genes involved in the synthesis of biologically active compounds. A wider range of biosynthetic genes was found in the genomes of streptomycetes than in other genera. These results coincide with the distribution of the antibiotic activity spectrum of the studied isolates.

Table 3. Enzymatic activities of actinobacteria associated with Polytrichum strictum

\begin{tabular}{|c|c|c|c|c|c|c|c|}
\hline Genus & Isolate & Pectinolytic & Amylolytic & Protease & Lecithinase & $\begin{array}{l}\text { Nitrate } \\
\text { reduction }\end{array}$ & Lipase \\
\hline \multirow[t]{14}{*}{ Micromonospora sp. } & Psp 67-01 & + & + & + & - & - & + \\
\hline & Psp 67-05 & - & + & + & - & - & - \\
\hline & Psp 67-08 & - & + & + & - & - & + \\
\hline & Psp 67-09 & - & + & + & - & - & + \\
\hline & Psp 67-10 & - & - & - & - & - & - \\
\hline & Psp 67-11.1 & - & - & - & - & + & - \\
\hline & Psp 67-11.2 & - & - & - & - & + & - \\
\hline & Psp 67-12 & - & + & - & - & + & + \\
\hline & Psp 67-16 & + & + & + & - & + & - \\
\hline & Psp 67-20 & - & - & - & - & - & - \\
\hline & Psp 67-22 & - & + & - & - & - & - \\
\hline & Psp 67-23 & - & + & + & - & - & + \\
\hline & Psp 67-24 & + & + & + & - & + & - \\
\hline & Psp 67-25 & - & + & + & - & - & + \\
\hline \multirow[t]{7}{*}{ Streptomyces sp. } & Psp 67-03 & + & + & + & + & + & + \\
\hline & Psp 67-13 & - & + & + & + & - & + \\
\hline & Psp 67-15 & - & + & + & + & - & + \\
\hline & Psp 67-19 & - & + & + & + & - & + \\
\hline & Psp 67-21 & + & + & - & + & - & + \\
\hline & Psp 67-27 & - & + & - & - & + & + \\
\hline & Psp 67-28 & - & + & - & - & + & + \\
\hline Kribbella sp. & Psp 67-02 & - & + & + & - & + & + \\
\hline Micrococcus sp. & Psp 67-29 & - & + & - & - & + & - \\
\hline
\end{tabular}




\begin{tabular}{|c|c|c|c|c|c|c|c|c|c|c|c|c|c|c|c|c|c|c|c|c|c|c|c|c|}
\hline 突 & 1 & 1 & 1 & 1 & 1 & 1 & 1 & 1 & 1 & 1 & 1 & 1 & 1 & 1 & 1 & 1 & 1 & 1 & I & 1 & 1 & + & 1 & $1 \stackrel{0}{3}$ \\
\hline$\sum^{0} \overleftarrow{J}$ & 1 & 1 & 1 & 1 & 1 & 1 & 1 & + & | & 1 & 1 & 1 & + & 1 & 1 & + & + & + & I & + & + & + & + & $\widehat{\widehat{0}}$ \\
\hline$\frac{\pi}{2}$ & 1 & 1 & 1 & 1 & + & 1 & 1 & 1 & + & + & 1 & + & 1 & + & + & 1 & + & + & + & + & + & + & + & \\
\hline 究 & 1 & + & + & 1 & 1 & 1 & 1 & + & + & 1 & 1 & + & + & + & 1 & + & + & + & + & + & + & + & + & \\
\hline $\begin{array}{l}\tilde{n} \\
\frac{a}{z}\end{array}$ & 1 & + & I & 1 & I & 1 & + & 1 & 1 & 1 & 1 & 1 & 1 & 1 & + & 1 & 1 & 1 & + & 1 & 1 & 1 & 1 & E \\
\hline $\begin{array}{l}= \\
\frac{n}{2} \\
\frac{v}{2}\end{array}$ & 1 & 1 & + & 1 & 1 & 1 & + & + & + & 1 & 1 & + & + & + & + & + & + & + & + & + & + & + & + & 2 \\
\hline $\begin{array}{l}\bar{n} \\
\frac{v}{2}\end{array}$ & 1 & + & + & I & + & 1 & + & + & + & + & + & + & + & + & I & + & + & + & + & + & + & + & + & \\
\hline 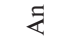 & + & 1 & + & 1 & 1 & 1 & 1 & 1 & 1 & 1 & 1 & 1 & + & + & + & + & + & + & 1 & + & + & + & 1 & \\
\hline 오 & + & 1 & 1 & 1 & 1 & 1 & + & + & + & I & 1 & 1 & + & + & + & + & + & + & + & + & + & + & I & \\
\hline ూீ & 1 & 1 & 1 & 1 & 1 & + & 1 & 1 & 1 & 1 & 1 & 1 & 1 & 1 & 1 & 1 & 1 & + & 1 & 1 & 1 & 1 & + & \\
\hline Z & 1 & 1 & I & 1 & 1 & 1 & 1 & 1 & 1 & 1 & 1 & 1 & 1 & I & + & 1 & 1 & 1 & 1 & 1 & 1 & 1 & 1 & \\
\hline 2 & 1 & 1 & 1 & 1 & 1 & 1 & 1 & 1 & 1 & I & 1 & 1 & 1 & 1 & 1 & 1 & 1 & 1 & 1 & + & 1 & 1 & 1 & \\
\hline$\infty$ & 1 & 1 & 1 & 1 & 1 & 1 & 1 & 1 & 1 & 1 & 1 & 1 & 1 & I & 1 & 1 & 1 & 1 & I & 1 & 1 & 1 & 1 & \\
\hline లี & 1 & 1 & 1 & 1 & 1 & 1 & 1 & 1 & 1 & 1 & 1 & 1 & 1 & 1 & 1 & + & + & + & 1 & 1 & 1 & 1 & 1 & $\dot{q}$ \\
\hline$\tilde{U}$ & 1 & I & I & 1 & I & I & 1 & 1 & I & 1 & I & 1 & 1 & I & I & + & + & + & I & 1 & 1 & 1 & 1 & \\
\hline$z$ & 1 & 1 & 1 & 1 & 1 & 1 & 1 & 1 & 1 & 1 & 1 & 1 & 1 & 1 & 1 & 1 & 1 & 1 & 1 & 1 & 1 & I & 1 & \\
\hline$\approx$ & 1 & 1 & 1 & 1 & 1 & 1 & 1 & 1 & 1 & 1 & 1 & 1 & 1 & I & 1 & 1 & 1 & 1 & I & 1 & 1 & 1 & 1 & \\
\hline 비 & 1 & 1 & 1 & 1 & 1 & 1 & 1 & 1 & 1 & 1 & 1 & 1 & 1 & I & 1 & 1 & 1 & 1 & I & 1 & 1 & 1 & 1 & \\
\hline$\sum^{n}$ & 1 & 1 & 1 & 1 & 1 & 1 & 1 & 1 & + & 1 & 1 & I & + & 1 & 1 & 1 & 1 & + & । & 1 & 1 & 1 & 1 & \\
\hline 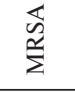 & 1 & 1 & 1 & 1 & 1 & 1 & 1 & 1 & 1 & 1 & 1 & 1 & 1 & I & + & 1 & 1 & 1 & I & 1 & 1 & 1 & 1 & $\dot{1}$ \\
\hline$\tilde{n}$ & 1 & 1 & 1 & 1 & 1 & + & 1 & 1 & 1 & 1 & 1 & I & I & I & + & 1 & 1 & 1 & । & 1 & 1 & 1 & 1 & \\
\hline$\ddot{\infty}$ & 1 & 1 & 1 & 1 & 1 & + & 1 & 1 & 1 & 1 & 1 & 1 & 1 & I & 1 & 1 & + & + & I & 1 & 1 & 1 & 1 & \\
\hline $\begin{array}{l}\stackrel{0}{\pi} \\
0 \\
0\end{array}$ & $\begin{array}{l}0 \\
i \\
i \\
0 \\
0 \\
0\end{array}$ & $\begin{array}{l}n \\
1 \\
i \\
0 \\
n^{2} \\
2\end{array}$ & $\begin{array}{l}\infty \\
0 \\
1 \\
b \\
0_{2} \\
2\end{array}$ & $\begin{array}{l}0 \\
0 \\
0 \\
\text { nे } \\
0\end{array}$ & $\begin{array}{l}\frac{0}{1} \\
\frac{1}{6} \\
\frac{2}{2} \\
2\end{array}$ & $\begin{array}{l}7 \\
\vdots \\
\frac{1}{0} \\
0 \\
0\end{array}$ & $\begin{array}{l}\frac{1}{1} \\
\frac{1}{b} \\
\text { के } \\
2\end{array}$ & $\begin{array}{l}\frac{1}{1} \\
\frac{1}{6} \\
\frac{0}{2} \\
0\end{array}$ & $\begin{array}{l}0 \\
\frac{1}{1} \\
6 \\
\frac{2}{2} \\
0\end{array}$ & $\begin{array}{l}\stackrel{1}{1} \\
\frac{1}{b} \\
n_{2} \\
2\end{array}$ & $\begin{array}{l}\tilde{1} \\
\frac{1}{6} \\
\text { nे } \\
2\end{array}$ & $\begin{array}{l}0 \\
\frac{1}{0} \\
0 \\
2 \\
2\end{array}$ & $\begin{array}{l}\stackrel{1}{N} \\
\frac{1}{0} \\
n_{2} \\
2\end{array}$ & $\begin{array}{l}2 \\
\frac{1}{1} \\
6 \\
2 \\
2\end{array}$ & $\begin{array}{l}3 \\
1 \\
1 \\
6 \\
2 \\
2\end{array}$ & $\begin{array}{l}\frac{9}{1} \\
\frac{1}{6} \\
2 \\
2\end{array}$ & $\begin{array}{l}\frac{1}{1} \\
\frac{1}{6} \\
\frac{2}{2}\end{array}$ & $\begin{array}{l}\frac{9}{1} \\
\frac{1}{2} \\
\frac{2}{2}\end{array}$ & $\begin{array}{l}\overrightarrow{1} \\
\frac{1}{0} \\
2 \\
0\end{array}$ & $\begin{array}{l}\hat{i} \\
\hat{b} \\
\hat{n} \\
2\end{array}$ & $\begin{array}{l}\infty \\
\frac{1}{1} \\
0 \\
0\end{array}$ & 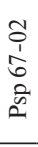 & $\begin{array}{l}2 \\
\frac{1}{b} \\
2 \\
2\end{array}$ & 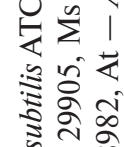 \\
\hline 号 & 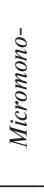 & 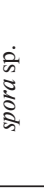 & & & & & & & & & & & & & 竞 & & & & & & & 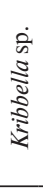 & 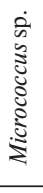 & 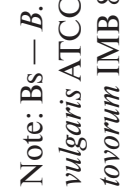 \\
\hline
\end{tabular}




\section{Discussion}

The plant rhizosphere is the "home" to various microorganisms, including actinobacteria (Berendsen et al., 2012). Mosses are one of the dominant components of the vegetation in the Antarctic (Parnikoza et al., 2018). The microbial diversity in soils associated with mosses may be greater than in soils free of plants (Kaštovská et al., 2005). However, some similar studies do not confirm this view (Learn-Han et al., 2012), and the problem requires further research. Moreover, so far, there are almost no data on the biotechnological potential of actinobacteria associated with mosses in Antarctica (Learn-Han et al., 2012; Raymond, 2016). This work focuses on the study of the diversity and characterization of actinobacteria associated with $P$. strictum. In our previous work, the biosynthetic potential of Antarctic actinobacteria isolated from the rhizosphere of Deschampsia antarctica É. Desv. 1837 (Poaceae) was demonstrated (Tistechok et al., 2019).

Moreover, the spectra of genera of actinobacteria associated with $P$. strictum and $D$. antarctica (unpublished data) are almost indistinguishable. The similarity of the spectra of the genera of actinobacteria between two different samples could be influenced by the same soil composition, as the samples were collected at a short distance from each other, and also the same isolation methods and media were used. This is confirmed by previously published data (Molina-Montenegro et al., 2019).

Most of the actinobacterial isolates belonged to the genus Micromonospora (14 strains). This is not typical because the usual dominant genus in populations of soil actinobacteria is Streptomyces. Most isolates of the genus Micromonospora were isolated after pretreatment with phenol, commonly used to isolate members of this genus (Hayakawa et al., 1991). These actinobacteria are widespread in various ecosystems, including desert soils and Antarctica (Hirsch et al., 2004; Carro et al., 2019). In addition, Micromonospora strains are a potential source of bioactive compounds, including important drugs such as aminoglycoside antibiotics (gentamicin, sagamicin, megalomicin, galomycin etc.) (Boumehira et al., 2016).

Seven isolates were affiliated to the genus Strepto- myces. The genus is widespread in the terrestrial ecosystems, especially in the soils, where it plays a significant role in soil formation. Also they are known as one of the most important sources of biologically active compounds, mainly antibiotics (Chater, 2013).

The isolates of the genera Micrococcus and Kribbella are also typical members of the soil microbiota. It should be noted that Micrococcus spp. are common on animals and human skins. The members of this genus are among the few bacteria that can synthesize long-chain (C21-C34) aliphatic hydrocarbons, which have a great potential in the biochemical industry (Kocur et al., 2006). Kribbella is a rare genus of actinobacteria that includes only 33 described species (List of Prokaryotic names with Standing in Nomenclature). This genus of actinobacteria was recently isolated from the rhizosphere of $D$. antarctica on King George Island (Silva et al., 2020).

The analysis of the cultural properties of natural isolates of microorganisms is a part of understanding their physiological characteristics and selecting the optimal conditions for cultivation in the laboratory. The periods of extremely low temperatures could have induced adaptive mechanisms in Antarctic microorganisms, the main of which are the cold-shock proteins, cold-active enzymes, antifreeze enzymes, and polysaccharides, etc. (Raymond, 2016; Muñoz et al., 2017). We found eight psychrotrophic isolates that grew well in the range of $4-37^{\circ} \mathrm{C}$ and may be of interest for further study of the mechanisms of their cold resistance.

However, low temperatures are not the only stress factor on Galindez Island. Antarctic soils are characterized by increased salinity which has a negative effect on plant growth and the ecosystem in general (Vasileva-Tonkova et al., 2014). It is known that microorganisms play an important role in reducing the adverse effects of salinity (Yasmin et al., 2020). Among the studied isolates, there were four halophilic strains, the members of the genera Streptomyces and Micromonospora.These isolates grew in the presence of $7.5 \% \mathrm{NaCl}$, and they can be used to further study the mechanisms of the salinity tolerance. Acidity is another crucial characteristic of the soil. The soils of Galindez Island are weakly acidic $(\mathrm{pH}$ 
4-6) (Parnikoza et al., 2017). This can be caused by the activity of living organisms, e.g., mosses, which actively metabolize Nitrogen (Neina, 2019). Although most isolates grew well in the range of $\mathrm{pH}$ 6-10, two isolates (Streptomyces sp. Psp 67-13 and Psp 67-15) could grow in a much wider range of $\mathrm{pH}$ values ( $\mathrm{pH} 4-12)$.

The rhizosphere microorganisms play a significant role in the growth and development of plants. A broad range of bioactive compounds (antibiotics, enzymes, phytohormones, etc.) produced by plant-associated actinobacteria can promote plant growth and protection against phytopathogens (Berendsen et al., 2012). These properties cause the formation of close mutualistic interactions in the system "plant-microorganism". Furthermore, actinobacteria can hydrolyze difficult to access substrates and improve the nutrition of the symbiont plants (Sathya et al., 2017). The isolates studied in this work produced cellulase, amylase, caseinase, lipase, nitrate reductase, and pectinase activities. Such enzymatic activity can provide the symbiont plants with available nutrient sources, contributing to their tolerance to extreme environmental conditions. In addition, the enzymes that can be active at low temperatures may be promising for use in food biotechnology (Muñoz et al., 2017). However, this aspect still requires further research.

Antarctic actinobacteria can produce a wide range of antibiotics despite extreme polar conditions, including new compounds (Núñez-Montero \& Barrientos, 2018). The composition of the nutrient medium has a significant effect on the production of bioactive secondary metabolites. Because of this, the study of the antimicrobial activities of actinobacteria associated with $P$. strictum was performed on three different media: NL19, DNPM, and ISP2. The approach has been demonstrated to be efficient (Axenov-Gribanov et al., 2016). Streptomycetes produced antimicrobial compounds on all used media. Micromonospora spp. and Kribella sp. Psp 67-02 in most cases inhibited the growth of some test cultures after cultivation on NL19 and DNPM media. The studied isolates had a significantly smaller spectrum of antimicrobial activity against used pathogens than isolates from more favorable biotopes (Gromyko, 2012).
At the same time, most of them inhibited the growth of at least one experimental culture of gram-positive bacterium or yeast. Among the streptomycetes isolates, we found antagonists of MDR clinical strains of $C$. albicans and $S$. aureus, which may be promising for screening of the antistaphylococcal or anticandidal compounds. A limited number of isolates inhibited the growth of phytopathogenic bacteria, while most isolates showed antifungal activity. As mentioned above, mosses predominate in more acidic environments, promoting the growth of filamentous fungi (Rosa et al., 2019). Therefore, it can lead to selection pressure and natural selection of symbiotic/ associated actinobacteria that can compete with fungi by producing antifungal compounds.

The screening of the biosynthetic genes involved in synthesizing a wide range of bioactive compounds (e. g. antibiotics) can reveal the biotechnological potential of isolated microorganisms. (Winn et al., 2016). The biosynthetic genes of types I and II PKS, CYP 450, and APH, which are responsible for the production of a significant number of antibiotics with different mechanisms of action, were identified in most of the isolated actinobacteria. Similar findings were reported by Encheva-Malinova et al. (2014). In the genomes of isolates belonging to the genus Streptomyces sp. more biosynthetic gene clusters were found than in members of the genus Micromonospora, in accordance with the fact that streptomycetes are leaders in the production of antibiotic compounds (Liu et al., 2018). A large number of biosynthetic genes in Kribbella sp. Psp 67-2 and Micrococcus sp. Psp 67-29 were also identified. However, the presence in the genomes of the studied isolates of many biosynthetic genes does not always correlate with the spectrum of their antimicrobial activities. For example, the isolate Micromonospora sp. Psp 67-05 was positive for PKS type I, NRSP, and CYP 450 genes screening but did not inhibit any used test culture. Similar results were obtained with other isolates of the genus Micromonospora (Psp 6720, Psp 67-22, Psp 67-23). In the genome of the isolate Kribbella sp Psp. 67-2 all the biosynthetic genes except NRPS were detected, but this strain showed only antifungal activity against phytopathogenic fungi. The absence of correlation between antimicrobial 
activity and the presence of biosynthetic genes might have several reasons. The studied biosynthetic genes may be in a cryptic state, or their expression was insufficient to detect antimicrobial activity. Moreover, these biosynthetic genes may be involved in the production of compounds that have no activity against the used test cultures (Tran et al., 2019).

Thus, the presented results complement the existing data on the diversity of actinobacteria in Antarctic biotopes. Furthermore, analysis of enzymatic and antimicrobial activities, as well as a screening of the biosynthetic genes, demonstrated the potential of isolated actinobacteria as producers of a wide range of biologically active compounds.

\section{Conclusions}

A total of 23 actinobacterial isolates associated with dominant Antarctic species P. strictum were isolated. Among them, members of the four genera Streptomyces (7 isolates), Micromonospora (14 isolates), Kribbella (1 isolate), and Micrococcus (1 isolate) were identified. Eight psychrotrophic strains from different genera capable of growing in the range of $4-37^{\circ} \mathrm{C}$ were isolated. The optimum growth conditions for all isolates were in the range of $\mathrm{pH}$ 6-10 and a temperature of $28-37^{\circ} \mathrm{C}$. Some isolates, such as Streptomyces sp. Psp 67-13 and Psp 67-15, grew at pH 4-12 and a temperature of $4-45^{\circ} \mathrm{C}$. Four isolates grew in the presence of $7.5 \% \mathrm{NaCl}$. A significant number of the isolates showed cellulase, protease, lipase, nitrate reductase, lecithinase, and pectinase activities. Among the studied actinobacteria isolates, six antagonists of gram-positive bacteria, three antagonists of typical and MDR strains of $C$. albicans, and one isolate active against MRSA were found. Some strains were active against phytopathogenic microorganisms, namely three strains against E. amylovora, one strain against $A$. tumefaciens, and one strain against $P$. carotovorum. More than half of the isolates showed antifungal activity against $F$. oxysporum and $A$. niger. The biosynthetic genes (PKS I and II, NRPS, CYP450, APH, HMG-CoA, and oxyB) involved in synthesizing a wide range of bioactive compounds were found in more than $80 \%$ of isolates.
Antarctic actinobacteria isolated in this study demonstrate potential as producers of a wide range of biologically active compounds. Further research of these actinobacteria may lead to the identification of previously unknown biologically active compounds.

Author contributions. OG conceived and planned the experiment. IP collected the sample and determined the moss species. ST performed the isolation, phylogenetic analysis, and contributed to the final version of the manuscript. IR performed the determination of cultural properties and screening of antimicrobial activity, OA performed the screening of biosynthetic genes. OG analysed the data, designed the tables and figures, and wrote the manuscript with input from IR and OA. VF and AL aided in interpreting the results. All authors read and approved the manuscript.

Funding. This study was performed and partially funded under the State Target Scientific and Technical Program of Research in Antarctica for 2011-2020 within project "Diversity of actinomycetes associated with moss Polytrichum sp. ((Karpaty Ridge, Galindez Island), and their potential as producers of antimicrobial compounds" (contract dated September 21, 2020 № H/02-2020).

Conflict of Interest. The authors declare that they have no conflict of interest.

\section{References}

Anderson, A. S., Clark, D. J., Gibbons, P. H., \& Sigmund, J. M. (2002). The detection of diverse aminoglycoside phosphotransferases within natural populations of actinomycetes. Journal of Industrial Microbiology and Biotechnology, 29(2), 60-69. https://doi.org/10.1038/sj.jim.7000260

Axenov-Gribanov, D. V., Voytsekhovskaya, I. V., Tokovenko, B. T., Protasov, E. S., Gamaiunov, S. V., Rebets, Y. V., Luzhetskyy, A.N., \& Timofeyev, M.A. (2016). Actinobacteria isolated from an underground lake and moonmilk speleothem from the biggest conglomeratic karstic cave in Siberia as sources of novel biologically active compounds. PLoS ONE,11(2), e0149216. https://doi.org/10.1371/journal.pone.0149216

Ayuso, A., Clark, D., González, I., Salazar, O., Anderson, A., \& Genilloud, O. (2005). A novel actinomycete strain de-replication approach based on the diversity of polyketide synthase and nonribosomal peptide synthetase biosynthetic pathways. Applied Microbiology and Biotechnology, 67, 795-806. https:// doi.org/10.1007/s00253-004-1828-7 
Ayuso-Sacido, A., \& Genilloud, O. (2005). New PCR primers for the screening of NRPS and PKS-I systems in actinomycetes: detection and distribution of these biosynthetic gene sequences in major taxonomic groups. Microbial Ecology, 49, 10-24. https://doi.org/10.1007/s00248-004-0249-6

Baltz, R. H. (2019). Natural product drug discovery in the genomic era: realities, conjectures, misconceptions, and opportunities. Journal of Industrial Microbiology and Biotechnology, 46 (3-4), 281-299. https://doi.org/10.1007/s10295-018- 2115-4

Bates, J. L., \& Liu, P. V. (1963). Complementation of lecithinase activities by closely related pseudomonads: Its taxonomic implication. Journal of bacteriology, 86(3), 585-592.

Berendsen, R. L., Pieterse, C. M. J., \& Bakker, P. A. H. M. (2012). The rhizosphere microbiome and plant health. Trends in Plant Science, 17(8), 478-486. https://doi.org/10.1016/j. tplants.2012.04.001

Boumehira, A. Z., El-Enshasy, H. A., Hacène, H., Elsayed, E. A., Aziz, R., \& Park, E. Y. (2016). Recent progress on the development of antibiotics from the genus Micromonospora. Biotechnology and Bioprocess Engineering, 21, 199-223. https://doi.org/10.1007/s12257-015-0574-2

Carro, L., Castro, J. F., Razmilic, V., Nouioui, I., Pan, C., Igual, J. M., Jaspars, M., Goodfellow, M., Bull, A.T., Asenio, J. A., \& Klenk, H.-P. (2019). Uncovering the potential of novel micromonosporae isolated from an extreme hyper-arid Atacama Desert soil. Scientific Reports, 9, 4678. https://doi. org/ 10.1038/s41598-019-38789-z

Chater, K. F. (2013). Streptomyces. In S. Maloy, K. Hughes (Eds.), Brenner's Encyclopedia of Genetics ( $2^{\text {nd }}$ ed., pp. 565567). Academic Press.

Ding, T., Yang L-G., Zhang, W-D., \& Shen, Y-H. (2019). The secondary metabolites of rare actinomycetes: chemistry and bioactivity. RSC Advances, 9(38), 21964-21988. https:// doi.org/10.1039/C9RA03579F

Egorov, N. S. (Ed.). (1995). Rukovodstvo k prakticheskim zanyatiyam po mikrobiologii [Guide to practical training in microbiology]. Moscow: Moscow State University. (in Russian)

Elbeltagy, A., Nishioka, K., Suzuki, H., Sato, T., Sato, Y.-I., Morisaki, H., Mitsui, H., \& Minamisawa, K. (2000). Isolation and characterization of endophytic bacteria from wild and traditionally cultivated rice varieties. Soil Science and Plant Nutrition, 46(3), 617-629. https://doi.org/10.1080/00380768. 2000.10409127

Encheva-Malinova, M., Stoyanova, M., Avramova, H., Pavlova, Y., Gocheva, B., Ivanova, I., \& Moncheva, P. (2014). Antibacterial potential of streptomycete strains from Antarctic soils. Biotechnology and Biotechnological Equipment, 28(4), 721-727. https://doi.org/10.1080/13102818.2014.947066

Felsenstein, J. (1985). Confidence limits on phylogenies: an approach using the bootstrap. Evolution, 39(4), 783-791. https://doi.org/10.1111/j.1558-5646.1985.tb00420.x

Gromyko, O. (2012). Antagonistic properties of actinomycetes from the ryzosphere of Olea europea L. Visnyk of the
Lviv University. Series Biology, 59, 209-215. http://prima.lnu. edu.ua/faculty/biologh/wis/english.htm (in Ukrainian)

Han, K., Kim, S., Park, H., Myeong, J., Park, N., \& Kim, E. (2010). Primer for detection of cytochrome P450 hydroxylase specific to polyene.U.S. Patent Application Publication, Pub. No: US 2010/0003669A1.

Hayakawa, M., Sadakata, T., Kajiura, T., \& Nonomura, H. (1991). New methods for the highly selective isolation of $\mathrm{Mi}$ cromonospora and Microbispora from soil. Journal of fermentation and bioengineering, 72(5), 320-326. https://doi.org/10. 1016/0922-338x(91)90080-z

Hirsch, P., Mevs, U., Kroppenstedt, R. M., Schumann, P., \& Stackebrandt, E. (2004). Cryptoendolithic actinomycetes from antarctic sandstone rock samples: Micromonospora endolithica sp. nov. and two isolates related to Micromonospora coerulea Jensen 1932. Systematic and Applied Microbiology, 27(2), 166-174. https://doi.org/10.1078/072320204322881781

Kasana, R. C., Salwan, R., Dhar, H., Dutt, S., \& Gulati, A. (2008). A rapid and easy method for the detection of microbial cellulases on agar plates using Gram's iodine. Current microbiology, 57(5), 503-507. https://doi.org/10.1007/s00284008-9276-8

Kaštovská, K., Elster, J., Stibal, M., \& Šantrůčková, H. (2005). Microbial assemblages in soil microbial succession after glacial retreat in Svalbard (High Arctic). Microbial Ecology, 50, 396. https://doi.org/10.1007/s00248-005-0246-4

Kearse, M., Moir, R., Wilson, A., Stones-Havas, S, Cheung, M., Sturrock, S., Buxton, S., Cooper, A., Markowitz, S., Duran, C., Thierer, T., Ashton, B., Meintjes, P., \& Drummond, A. (2012). Geneious Basic: an integrated and extendable desktop software platform for the organization and analysis of sequence data. Bioinformatics, 28(12), 1647-1649. https:// doi.org/10.1093/bioinformatics/bts199

Kieser, T., Bibb, M. J., Buttner, M. J., Chater, K. F., \& Hopwood, D. A. (2000). Practical Streptromyces genetics. John Innes Foundation.

Kimura, M. (1980). A simple method for estimating evolutionary rates of base substitutions through comparative studies of nucleotide sequences. Journal of Molecular Evolution,16, 111-120. https://doi.org/10.1007/BF01731581

Kocur, M., Kloos, W. E., \& Schleifer, K.-H. (2006). The genus Micrococcus. In M. Dworkin, S. Falkow, E. Rosenberg, K.-H. Schleifer, E. Stackebrandt (Eds.), The Prokaryotes (pp. 961971). Springer. https://doi.org/10.1007/0-387-30743-5_37

Kumar, S., Stecher, G., Li, M., Knyaz, C., \& Tamura, K. (2018). MEGA X: Molecular evolutionary genetics analysis across computing platforms. Molecular Biology and Evolution, 35(6), 1547-1549. https://doi.org/10.1093/molbev/msy096

Learn-Han, L., Yoke-Kqueen, C., Shiran, M. S., VuiLing, C. M. W., Nurul-Syakima, A. M., Son, R., \& Andrade, H. M. (2012). Identification of actinomycete communities in Antarctic soil from Barrientos Island using PCR-denaturing gradient gel electrophoresis. Genetics and Molecular Research, 11(1), 277-291. https://doi.org/10.4238/2012.February.8.3 
Levin, L. N., Hernández-Luna, C. E., Niño-Medina, G., García-Rodríguez, J. P., López-Sadin, I., Méndez-Zamora, G., \& Gutiérrez-Soto, G. (2019). Decolorization and Detoxification of Synthetic Dyes by Mexican Strains of Trametes sp. International Journal of Environmental Research and Public Health, 16(23), 4610. https://doi.org/10.3390/ijerph16234610

List of Prokaryotic names with Standing in Nomenclature. Retrieved March 10, 2021, from https://lpsn.dsmz.de/genus/ kribbella

Liu, R., Deng, Z., \& Liu, T. (2018). Streptomyces species: ideal chassis for natural product discovery and overproduction. Metabolic Engineering, 50, 74-84. https://doi.org/10.1016/ j.ymben.2018.05.015

Mazzini, S., Musso, L., Dallavalle, S., \& Artali, R. (2020). Putative SARS-CoV-2 $\mathrm{M}^{\text {pro }}$ inhibitors from an in-house library of natural and nature-inspired products: a virtual screening and molecular docking study. Molecules, 25(16), 3745. https://doi.org/10.3390/molecules25163745

Molina-Montenegro, M. A., Ballesteros, G. I., Castro-Nallar, E., Meneses, C., Gallardo-Cerda, J., \& Torres-Diaz, C. (2019). A first insight into the structure and function of rhizosphere microbiota in Antarctic plants using shotgun metagenomic. Polar Biology, 42, 1825-1835. https://doi.org/10.1007/ s00300-019-02556-7

Moradi, A., Tahmourespour, A., Hoodaji, M., \& Khorsandi, F. (2011). Effect of salinity on free living-diazotroph and total bacterial populations of two saline soils. African Journal of Microbiology Research, 5(2), 144-148. https://academicjournals.org/journal/AJMR/article-abstract/A0246DF13046

Muñoz, P. A., Márquez, S. L., González-Nilo, F. D., Márquez-Miranda, V., \& Blamey, J. M. (2017). Structure and application of antifreeze proteins from Antarctic bacteria. $\mathrm{Mi}$ crobial Cell Factories, 16, 138. https://doi.org/10.1186/s129 34-017-0737-2

Neina, D. (2019). The role of soil pH in plant nutrition and soil remediation. Applied and Environmental Soil Science, Article 5794869. https://doi.org/10.1155/2019/5794869

Núñez-Montero, K., \& Barrientos, L. (2018). Advances in antarctic research for antimicrobial discovery: a comprehensive narrative review of bacteria from antarctic environments as potential sources of novel antibiotic compounds against human pathogens and microorganisms of industrial importance. Antibiotics (Basel), 7(4), 90. https://doi.org/10.3390/ antibiotics 7040090

Parnikoza, I., Abakumov, E., Korsun, S., Klymenko, I., Netsyk, M., Kudinova, A., \& Kozeretska, I. (2017). Soils of the Argentine Islands, Antarctica: diversity and characteristics. Polarforschung, 86 (2), 83-96. https://doi.org/10.2312/polarforschung. 86.2.83

Parnikoza, I., Berezkina, A., Moiseyenko, Y., Malanchuk, V., \& Kunakh, V. (2018). Complex survey of the Argentine Islands and Galindez Island (Maritime Antarctic) as a research area for studying the dynamics of terrestrial vegetation. Ukrainian
Antarctic Journal, 1(17), 73-101. https://doi.org/10.33275/ 1727-7485.1(17).2018.34 (in Ukrainian)

Pei, C.-X., Liu, Q., Dong, C.-S., Li, H. Q., Jiang, J.-B., \& Gao,W.-J. (2010). Diversity and abundance of the bacterial 16S rRNA gene sequences in forestomach of alpacas (Lama pacos) and sheep (Ovis aries). Anaerobe, 16(4), 426-432. https:// doi.org/10.1016/j.anaerobe.2010.06.004

Petrus, M. L. C., \& Claessen, D. (2014). Pivotal roles for Streptomyces cell surface polymers in morphological differentiation, attachment and mycelial architecture. Antonie Van Leeuwenhoek, 106(1), 127-139. https://doi.org/10.1007/s10482014-0157-9

Pudasaini, S., Wilson, J., Mukan, J., van Dorst, J., Snape, I., Palmer, A. S., Burns, B. P., \& Ferrari, B. C. (2017). Microbial diversity of Browning peninsula, Eastern Antarctica revealed using molecular and cultivation methods. Frontiers in Microbiology, 8, 591. https://doi.org/10.3389/fmicb.2017.00591

Raju, R., Gromyko, O., Fedorenko, V., Luzhetskyy, A., \& Muller, R. (2012). Leopolic acid A, isolated from a terrestrial actinomycete, Streptomyces sp. Tetrahedron Letters, 53(46), 6300-6301. http://doi.org/10.1016/j.tetlet.2012.09.046

Raju, R., Gromyko, O., Fedorenko, V., Luzhetskyy, A., \& Muller, R. (2013). Oleaceran: anovel spiro[isobenzofuran-1, 2'-naptho[1,8-bc]furan] isolated from a terrestrial Streptomyces sp. Organic Letters, 15(14), 3487-3489. http://doi.org/ 10.1021/ol401490u

Raju, R., Gromyko, O., Fedorenko, V., Luzhetskyy, A., \& Muller, R. (2015). Albaflavenol B, a new sesquiterpene isolated from the terrestrial actinomycete, Streptomyces sp. Journal of Antibiotics, 68, 286-288. http://doi.org/10.1038/ja. 2014.138

Raymond, J. A. (2016). Dependence on epiphytic bacteria for freezing protection in an Antarctic moss, Bryum argenteum. Environmental Microbiology Reports, 8(1), 14-19. https://doi. org/10.1111/1758-2229.12337

Rosa, L. H., Zani, L. C., Cantrell, C. L., Duke, S. O., Dijck, P. V., Desideri, A., \& Rosa, C. A. (2019). Fungi in Antarctica: diversity, ecology, effects of climate change, and bioprospection for bioactive compounds. In L. H. Rosa (Ed.), Fungi of Antarctica (pp. 1-17). Springer, Cham. https://doi.org/10. 1007/ 978-3-030-18367-7_1

Saitou, N., \& Nei, M. (1987). The neighbor-joining method: a new method for reconstructing phylogenetic trees. Molecular Biology and Evolution, 4(4), 406-425. https://doi.org/10. 1093/oxfordjournals.molbev.a040454

Sathya, A., Vijayabharathi, R., \& Gopalakrishnan, S. (2017). Plant growth-promoting actinobacteria: a new strategy for enhancing sustainable production and protection of grain legumes. 3 Biotech, 7, 102. https://doi.org/10.1007/s13205-017- 0736-3

Sigmund, J. M., Clark, D. C., Rainey, F. A., \& Anderson, A. S. (2003). Detection of eubacterial 3-hydroxy-3-methylglutaryl coenzyme a reductases from natural populations of actinomycetes. Microbial Ecology, 46, 106-112. https://doi.org/ 10.1007/s00248-002-2029-5 
Silva, L. J., Crevelin, E. J., Souza, D. T., Lacerda-Júnior, G. V., de Olideria, V. M., Ruitz, A. L. T. G., Rosa, L. H., Moraes, L. A. B., \& Melo, I. S. (2020). Actinobacteria from Antarctica as a source for anticancer discovery. Scientific Reports, 10, 13870. https://doi.org/10.1038/s41598-020-69786-2

Strickler, K. M., Fremier, A. K., \& Goldberg, C. S. (2015). Quantifying effects of UV-B, temperature, and $\mathrm{pH}$ on eDNA degradation in aquatic microcosms. Biological Conservation, 183, 85-92. https://doi.org/10.1016/j.biocon.2014.11.038

Tistechok, S., Skvortsova, M., Luzhetskyy, A., Fedorenko, V., Parnikoza, I., \& Gromyko, O. (2019). Antagonistic and plant growth promoting properties of actinomycetes from rhizosphere Deschampsia antarctica E. Desv. (Galindez Island, Antarctica). Ukrainian Antarctic Journal, 1(18), 169-177. https://doi.org/10.33275/1727-7485.1(18).2019.140

Tran, P. N., Yen, M.-R., Chiang, C.-Y., Lin, H.-C., \& Chen, P.-Y. (2019). Detecting and prioritizing biosynthetic gene clusters for bioactive compounds in bacteria and fungi. Applied Microbiology and Biotechnology, 103, 3277-3287. https://doi.org/10.1007/s00253-019-09708-Z

Unuofin, J. O., Okoh, A. I., \& Nwodo, U. U. (2019). Recovery of laccase-producing gammaproteobacteria from wastewater. Biotechnology Reports, 21, e00320. https://doi.org/10. 1016/j.btre.2019.e00320

Vasileva-Tonkova, E., Romanovskaya, V., Gladka, G., Gouliamova, D., Tomova, I., Stoilova-Disheva, M., \& Tashyrev, O. (2014). Ecophysiological properties of cultivable heterotrophic bacteria and yeasts dominating in phytocenoses of Galindez Island, maritime Antarctica. World Journal of Mic- robiology and Biotechnology, 30(4), 1387-1398. https://doi. org/10.1007/s11274-013-1555-2

Wang, Q., Garrity, G. M., Tiedje, J. M., \& Cole, J. R. (2007). Naïve bayesian classifier for rapid assignment of rRNA sequences into the new bacterial taxonomy. Applied and Environmental Microbiology, 73(16), 5261-5267. https://doi. org/10.1128/AEM.00062-07

Winn, M., Fyans, J. K., Zhuo, Y., \& Micklefield, J. (2016). Recent advances in engineering nonribosomal peptide assembly lines. Natural Product Reports, 33, 317-347. https://doi. org/10.1039/c5np00099h

Wood, S. A., Kirby, B. M., Goodwin, C. M., Le Roes, M., \& Meyers, P. R. (2007). PCR screening reveals unexpected antibiotic biosynthetic potential in Amycolatopsis sp. strain UM16. Journal of applied microbiology, 102(1), 245-253. https://doi.org/10.1111/j.1365-2672.2006.03043.x

Yasmin, H., Naeem, S., Bakhtawar, M., Jabeen, Z., Nosheen, A., Naz, R., Keyani, R., Mumtaz, S., \& Hassan, M. N. (2020). Halotolerant rhizobacteria Pseudomonas pseudoalcaligenes and Bacillus subtilis mediate systemic tolerance in hydroponically grown soybean (Glycine $\max$ L.) against salinity stress. PloS One, 15(4), e0231348. https://doi.org/10.1371/ journal.pone. 0231348

Zhang, J. \& Zhang, L. (2011). Improvement of an isolation medium for actinomycetes. Modern Applied Science, 5(2), 124-127. https://doi.org/10.5539/mas.v5n2p124

Received: 15 March 2021 Accepted: 22 June 2021

\section{О. Громико ${ }^{1, *}$, С. Тістечок ${ }^{1}$, I. Роман ${ }^{1}$, О. Аравіцька ${ }^{1}$,} А. Лужецький ${ }^{4}$, I. Парнікоза ${ }^{2,3}$, В. Федоренко ${ }^{1}$

1 Львівський національний університет імені Івана Франка, м. Львів, 79005, Україна

2 Державна установа Національний антарктичний науковий центр МОН України, м. Київ, 01601, Україна

${ }^{3}$ Інститут молекулярної біології і генетики НАН України, м. Київ, 03143, Україна

${ }^{4}$ Університет Саарланду, м. Саарбрюкен, 66123, Німеччина

* Автор для кореспонденції: oleksandr.gromyko@lnu.edu.ua

Виділення і характеристика культурабельних актинобактерій, асоційованих з Polytrichum strictum (о. Галіндез, морська Антарктика)

Реферат. Метою роботи є оцінка різноманіття актинобактерій, асоційованих з Polytrichum strictum - видом домінантом поширеного антарктичного угруповання торф'янистих мохів, та їхня характеристика як продуцентів біологічно активних речовин. Ізоляти актинобактерій виділяли шляхом прямого висівання та попередньої обробки зразків розчином фенолу та прожарюванням. Культуральні властивості досліджували з використанням діагностичних середовищ. Антимікробну активність вивчали методом подвійних культур. Філогенетичний аналіз базувався на аналізі послідовності гена $16 \mathrm{~S}$ рРНК. Скринінг біосинтетичних генів здійснювали за допомогою ПЛР з використанням специ- 
фічних праймерів. Зі зразків P. strictum ізольовано 23 штами актинобактерій 4 родів: Streptomyces (7 ізолятів), Micromonospora (14 ізолятів), Kribbella (1 ізолят) та Micrococcus (1 ізолят). Виявлено вісім психротрофних штамів усіх ідентифікованих родів. Оптимум рН середовища для росту становив від 6 до 10. Чотири ізоляти росли в присутності 7,5\% $\mathrm{NaCl}$. Значна кількість ізолятів виявляла широкий спектр ферментативних активностей. Серед досліджених ізолятів актинобактерій виявлено антагоністів широкого спектру патогенних мікроорганізмів, у тому числі мультирезистентного штаму Candida albicans та метицилін-резистентного штаму Staphylococcus aureus. Деякі штами затримували ріст фітопатогенних бактерій: три штами - Erwinia amylovora, по одному штаму - Agrobacterium tumifaciens і Pectobacterium carotovorum. Більше половини ізолятів виявляли антифунгальну активність проти Fusarium oxysporum і Aspergillus niger. Гени біосинтезу, що беруть участь у синтезі широкого спектру біоактивних сполук, були виявлені у більш ніж $80 \%$ ізолятів. Антарктичні актинобактерії, виділені в цьому дослідженні, демонструють потенціал як продуценти широкого спектру біологічно активних сполук. Подальші дослідження цих ізолятів можуть призвести до ідентифікації раніше невідомих біологічно активних сполук.

Ключові слова: антарктичні актинобактерії, Polytrichum strictum, антимікробна активність, біосинтетичні гени 